\title{
Induksi Embriogenesis Somatik Pada Anggrek Vanda Sumatrana Schltr. dengan Penambahan Beberapa Konsentrasi Asam 2,4-Diklorofenoksiasetat (2,4-D)
}

\section{(Induction Somatic Embryogenesis of Orchid Vanda Sumatrana Schltr. with 2,4- Diclorofenoxiacetad Acid (2,4-D) Addition)}

\author{
Anita Tri Astuti"), Zozy Aneloi Noli, Suwirmen \\ Laboratorium Fisiologi Tumbuhan dan Kultur Jaringan, Jurusan Biologi, FMIPA Universitas Andalas, \\ Kampus UNAND Limau Manis Padang -25613 \\ *)Koresponden : Anitatria.11@gmail.com
}

\begin{abstract}
The research about induction of somatic embryogenesis of Orchid Vanda sumatrana Schltr. by giving 2,4-Diclorophenoxiacetic acid (2,4-D), was conducted from May to July 2016 in plant Physiology and tissue Culture Laboratory, Biology Departement, Matematics and Natural Science Faculty, Andalas University. The aim of this study was found the concentration of 2,4-D to induce somatic embryogenesis of Vanda sumatrana. The research used Completely Randomized Resign (CDR) with 6 treatments and 4 replication. The treatments were : without 2,4-D (control); $1 \mathrm{mg} / \mathrm{L} ; 2$ $\mathrm{mg} / \mathrm{L} ; 3 \mathrm{mg} / \mathrm{L} ; 4 \mathrm{mg} / \mathrm{L} ; 5 \mathrm{mg} / \mathrm{L}$. The result showed that $2 \mathrm{mg} / \mathrm{L} \mathrm{2,4-D} \mathrm{and} 3 \mathrm{mg} / \mathrm{L} \mathrm{2,4-D} \mathrm{were}$ concentrations to induct somatic embryogenesis.
\end{abstract}

Keywords: Somatic Embryogenesis, 2,4-D, Vanda sumatrana Schltr.

\section{Pendahuluan}

Vanda sumatrana merupakan tanaman endemik pulau Sumatera (Comber, 2001) Jenis $V$. sumatrana dapat ditemukan dibeberapa provinsi di pulau Sumatera mulai dari Aceh sampai Lampung (Comber, 2001). Dr. A. H Schrage mengatakan penyebaran $V$. sumatrana terdapat di pulau Samosir (Danau toba), anggrek ini juga banyak di temukan, di Sumatera Barat: Agam, Ngarai (Bukittinggi), Lampung : Batas Lampung-Palembang (Latif, 1960). Anggrek Vanda sumatrana digemari karena keindahan dan kecantikan bunganya, kebutuhan anggrek yang kian meningkat perlu ditunjang dengan penyediaan bibit dalam jumlah banyak dan dalam waktu yang singkat, kualitas yang unggul. Salah satu permasalahan dalam budidaya anggrek, khususnya genus Vanda, adalah masa vegetatif yang panjang, sehingga saat (waktu) pembungaan (flowering) membutuhkan waktu yang relatif lama (Dwiyani, 2013). Secara umum anggrek juga termasuk tanaman yang sulit dikembangbiakkan dikarenakan bijinya tidak memiliki endosperm sehingga sulit tumbuh di alam (Arditti, dan Ernst, 1993). Solusi terbaik yang dapat dilakukan adalah melalui perbanyakan in vitro, Perbanyakan secara in vitro merupakan sarana efektif dan potensial untuk mendapatkan bibit yang baik dan cepat (Suwirmen, 2009).

Perbanyakan $V$. sumatrana secara in vitro dapat dilakukan dengan dua cara yaitu dengan organogenesis dan embriogenesis somatik. Reg enerasi melalui embriogenesis somatik memberikan banyak keuntungan, antara lain waktu perbanyakan lebih cepat, pencapaian hasil dalam mendukung program perbaikan tanaman lebih cepat dan jumlah bibit yang dihasilkan tidak terbatas jumlahnya (Mariska, 2001).

Pemberian 2,4-D dengan Konsentrasi 0,2 $\mathrm{mg} / \mathrm{L}$ berhasil menginduksi embrio somatik pada tanaman anggrek Phalaenopsis sp L. 
oleh Rianawati, et, al. (2009) sedangkan Saputra (2012) berhasil menginduksi embrio somatik pada tanaman Phalaenopsis amabilis (L.) Blume dengan pemberian 2,4-D pada konsentrasi $1 \mathrm{mg} / \mathrm{l}$. Naing, et, al. (2011) juga berhasil menginduksi embriogenesis somatik pada tanaman Coelogyne cristata dengan pemberian 2,4-D $2 \mathrm{mg} / \mathrm{L}$. Dwiyani (2013) berhasil menginduksi kalus Vanda tricolor Lindl. Var. Suavis bersifat embrionik pada

Penelitian ini menggunakan metode eksperimen, memakai Rancangan Acak Lengkap (RAL) dengan enam perlakuan dan empat ulangan. Sebagai perlakuan adalah tanpa zat pengatur tumbuh (kontrol), $1 \mathrm{mg} / \mathrm{L}$ 2,4-D, $2 \mathrm{mg} / \mathrm{L}$ 2,4-D, 3 $\mathrm{mg} / \mathrm{L}$ 2,4-D, 4 mg/L 2,4-D, dan 5 , mg/L 2,4D. Sumber eksplan yang digunakan adalah daun muda. Prosedur kerja sesuai prosedur kultur jaringan secara baku (Hendaryono dan Wijayani, 1994). Parameter pengamatan yang diamati yaitu persentase eksplan yang hidup, Respon Eksplan dan Persentase

\section{Hasil dan Pembahasan}

Persentase Hidup Eksplan

Pemberian beberapa konsentrasi berbeda mempengaruhi respon hidup terhadap eksplan $V$. sumatrana sampai 12 minggu setelah tanam, mulai dari konsentrasi 2 sampai 4 $\mathrm{mg} / \mathrm{L}$ (Tabel 1) sedangkan pada perlakuan kontrol tidak memberikan respon terhadap pertumbuhan eksplan, sedangkan pemberian konsentrasi $5 \mathrm{mg} / \mathrm{L}$ 2,4-D eksplan mengalami kematian jaringan, hal ini karena konsentrasi 2,4-D yang diberikan terlalu tinggi bersifat toksik sehingga mengurangi kemampuan eksplan untuk berregenerasi. Hal ini menunjukan bahwa zat pengaruh tumbuh mempengaruhi keberhasilan pertumbuhan eksplan. Menurut Lizawati, et al. (2012) asam 2,4-D yang diberikan kedalam media kultur mampu menginduksi sel-sel yang berpotensi untuk melakukan pembelahan pemberian 2,4-D $2 \mathrm{mg} / \mathrm{L}$. Kemudian Hoesen, et, al. (2008) berhasil menginduksi embriogenesis dari kalus Dendrobium lineale Rofle. dengan pemberian 2,4-D $5 \mathrm{mg} / \mathrm{l}$. Penelitian ini dilakukan untuk mengetahui konsentrasi asam 2,4-Diklorofenoksiasetat yang mampu menginduksi pembentukan embriogenesis somatik pada V. Sumatrana

\section{Metode Penelitian}

Embrio Somatik yang Terbentuk, tekstur kalus, dan berat basah kalus. Pengamatan dilakukan setiap hari selama 12 minggu setelah tanam. Data yang diperoleh dianalisis secara statistik dan deskriptif. persentase eksplan yang hidup, Respon Eksplan dan Persentase Embrio Somatik yang Terbentuk, tekstur kalus disajikan secara deskriptif. Berat basah kalus di analisa secara statistik. Apabila pengaruh perlakuan berbeda nyata maka dilanjutkan uji Duncan New Multiple Range Test (DNMRT) pada taraf peluang 1dan $5 \%$

secara terus menerus, sedangkan tanpa pemberian zat pengatur tumbuh 2,4-D (Kontrol) eksplan tidak memperlihatkan respon hidup, ditandai dengan tidak adanya bagian sel yang berkembang dan eksplan berubah warna menjadi kehitaman. Menurut Collin dan Edward (1998) penambahan 2,4-D didalam media MS yang terlalu rendah tidak akan memberikan respon yang baik terhadap pertumbuhan eksplan. 
Tabel 1. Persentase hidup eksplan daun V. sumatrana pada medium MS dengan Pemberian 2,4-D pada 12 minggu setelah tanam.

\begin{tabular}{lc}
\hline \multicolumn{1}{c}{ Perlakuan } & Persentase hidup eksplan (\%) \\
\hline A. Kontrol & 0 \\
B. $1 \mathrm{mg} / \mathrm{L} 2,4-\mathrm{D}$ & 0 \\
C. $2 \mathrm{mg} / \mathrm{L} 2,4-\mathrm{D}$ & 100 \\
D. $3 \mathrm{mg} / 2,4-\mathrm{D}$ & 100 \\
E. $4 \mathrm{mg} / \mathrm{L} 2,4-\mathrm{D}$ & 50 \\
F. $5 \mathrm{mg} / \mathrm{L}$ 2,4-D & 0 \\
\hline
\end{tabular}

Respon hidup eksplan juga menunjukan pembentukan kalus yang dimulai pada konsentrasi 2 mg/L 2,4-D (Tabel 2). Hal ini menandakan bahwa pertumbuhan eksplan juga dipengaruhi oleh interaksi antara eksplan dan zat pengatur tumbuh pada media MS. Menurut Gardner et al. (1991), respons tanaman terhadap hormon dan zat pengatur tumbuh sangat bervariasi tergantung pada kepekaan organ tersebut. Menurut Collin dan Edward (1998) level zat pengatur tumbuh merupakan faktor yang sangat menetukan keberhasilan hidup eksplan berupa pertumbuhan kalus suspensi sel dan diferensiasi.

\section{Respon dan Persentase Eksplan yang} Membentuk Embrio Somatik

Pemberian konsentrasi 2,4-D yang berbeda mampu menginduksi embrio somatik pada eksplan $V$. sumatrana (Tabel 2). Pada pemberian konsentrasi 2 dan $3 \mathrm{mg} / \mathrm{L}$ 2,4-D mampu menginduksi embrio somatik pada minggu ke 12 setelah penanaman. Hal dikarena kan zat pengatur tumbuh 2,4-D pada konsentrasi 2 dan $3 \mathrm{mg} / \mathrm{L}$ merupakan konsentrasi yang optimum dalam menginduksi embrio somatik pada eksplant $V$. sumatrana. Naing, et.al (2011) melaporkan keberhasilan induksi embriogenesis somatik pada tanaman Coleogyne cristata dengan pemberian 2,4-D $2 \mathrm{mg} / \mathrm{L}$. Dwiyani (2013) juga melaporkan induksi kalus yang bersifat embrionik pada tanaman Vanda tricolor Lindl. Var. Suavis pada konsentrasi 2,4-D 2 $\mathrm{mg} / \mathrm{L}$.

Pada hasil pengamatan yang telah dilakukan embrio somatik yang terbentuk juga memperlihatkan, bahwa tidak semua bagian eksplan yang berkalus dapat membentuk embrio somatik. Dapat dilihat pada pemberian konsentrasi $4 \mathrm{mg} / \mathrm{L}$ terbentuk kalus berstruktur kompak dan berwarna coklat namun nonembriogenik (Gambar 1e). Warna coklat pada eksplan menandakan bahwa eksplan mengalami browning atau pencoklatan. Menurut Zaid (1987), terjadinya pencoklatan disebabkan tingginya senyawa fenol pada eksplan yang dapat menghambat pertumbuhan eksplan bahkan dapat mengakibat kan eksplan mati.

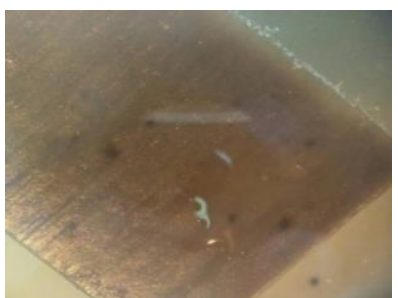

(a)

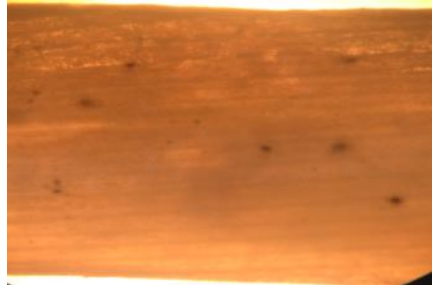

(b)

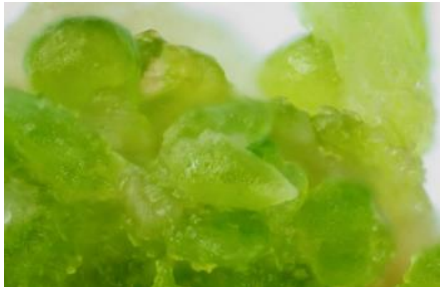

(c) 


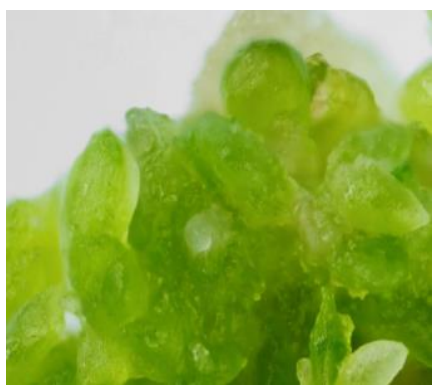

(d)

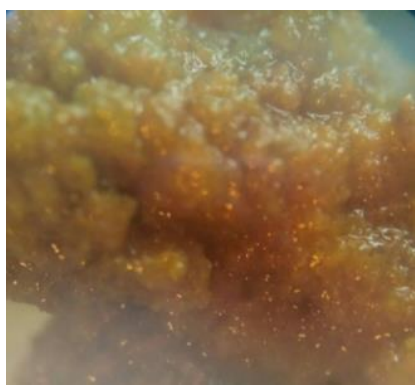

(e)

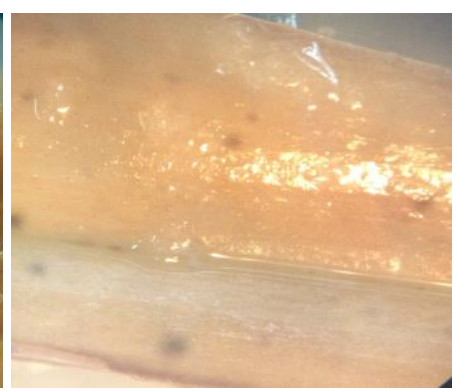

(f)

Gambar 1. Respon eksplan dari daun V. sumatrana pada perlakuan (a) tanpa 2,4-D, tidak ada respon (b) 1 mg/L 2,4-D, tidak ada respon (c) $2 \mathrm{mg} / \mathrm{L}$ 2,4-D, membentuk kalus remah embrio somatik fase globular (d) $3 \mathrm{mg} / \mathrm{L} 2,4-\mathrm{D}$, membentuk kalus remah embrio somatik fase globular (e) $4 \mathrm{mg} / \mathrm{L} 2,4-\mathrm{D}$, membentuk kalus kompak nonembrionik (f) $5 \mathrm{mg} / \mathrm{L} 2,4-\mathrm{D}$, tidak ada respon

Tabel 2. Respon eksplan V. sumatrana yang membentuk embrio somatik dan persentase eksplan yang membentuk embrio somatik pada medium MS dengan pemberian 2,4-D pada mingu ke 12 setelah tanam.

\begin{tabular}{lcccc}
\hline Konsentrasi & $\begin{array}{c}\text { Tahapan } \\
\text { Embrio } \\
\text { Somatik Yang } \\
\text { Terbentuk }\end{array}$ & $\begin{array}{c}\text { Jumlah eksplan } \\
\text { yang membentuk } \\
\text { Embrio Somatik } \\
(\%)\end{array}$ & $\begin{array}{c}\text { Tekstur } \\
\text { Kalus }\end{array}$ & $\begin{array}{c}\text { Terbentuknya } \\
\text { kalus }\end{array}$ \\
\hline A. Kontrol & Tidak terbentuk & 0 & Tidak terbentuk & Tidak terbentuk \\
B. $1 \mathrm{mg} / \mathrm{L}$ 2,4-D & Tidak terbentuk & 0 & Tidak terbentuk & Tidak terbentuk \\
C. $2 \mathrm{mg} / \mathrm{L}$ 2,4-D & Globular & 25 & Remah & Terbentuk \\
D. $3 \mathrm{mg} / \mathrm{L}$ 2,4-D & Globular & 75 & Remah & Terbentuk \\
E. $4 \mathrm{mg} / \mathrm{L}$ 2,4-D & Tidak terbentuk & 0 & Kompak & Terbentuk \\
F. $5 \mathrm{mg} / \mathrm{L}$ 2,4-D & Tidak terbentuk & 0 & & Tidak terbentuk
\end{tabular}

Pada penelitian yang telah dilakukan, embriogenesis somatik tidak terbentuk pada perlakuan kontrol dan perlakuan pembemberian konsentrasi 1 dan $5 \mathrm{mg} / \mathrm{L} 2,4-$ D. Sel embriogenesis somatik yang tidak muncul pada perlakuan kontrol dan pemberian 2,4-D konsentrasi $1 \mathrm{mg} / \mathrm{L}$ diduga karena auksin endogen pada eksplan daun $V$. sumatrana belum mampu menginduksi kalus, dengan kata lain eksplan mempunyai kandungan auksin yang rendah, sehingga masih membutuhkan tambahan auksin eksogen pada media kultur. Menurut Narayanaswamy (1994), setiap eksplan yang berasal dari organ dan spesies yang berbeda akan membutuhkan zat pengatur tumbuh yang berbeda pula. Hal ini juga diperkuat oleh Klaus Dan Haensch (2007) bahwa perlakuan tanpa 2,4-D tidak menunjukkan pembentukan embriogenesis somatik. Pada konsentrasi 5 mg/L 2,4-D juga tidak terbentuk embriogenesis somatik pada eksplan $V$. sumatrana. Hal ini disebabkan karena zat pengatur tumbuh 2,4-D merupakan auksin yang kuat sehingga jika diberikan pada konsentrasi tinggi dapat menyebabkan kematian jaringan pada eksplan.

Pada penelitian yang telah dilakukan embrio somatik terbantuk melalui jalur tidak langsung karena melewati proses kalus. Pada minggu ke 10 teramati bentuk kalus yang mulai bermunculan nodul-nodul yang berkembang menjadi embrio somatik. Menurut Fintarti (2010), ciri-ciri kalus bersifat embrionik ditandai dengan adanya nodul-nodul yang kemudian akan berkembang memasuki fase embrio somatik. Menurut Widuri et, al (2015) kalus embriogenik memiliki ciri berwarna hujau kekuningan, berstruktur remah dan kering 
sedangkan kalus non embriogenik berstruktur kompak, basah, dan berwarna bening kecoklatan.

Hasil pengamatan memperlihatkan bahwa fase embrio somatik pada media MS adalah fase globular, ditandai dengan terbentuknya nodul-nodul yang berbentuk bulat padat serta memiliki warna hijau (Gambar 1c,d). Menurut Fadhilah (2016), fase globular biasanya lebih mudah diamati karena bentuknya yang bulat spesifik. Sedangkan menurut Utami et. al.,(2007), fase globular pada embrio somatik biasanya dicirikan dengan warna hijau kekuningan berbentuk remah, mengkilat dan berdinding tipis.

Pada pengamatan embrio somatik yang terbentuk memperlihatkan tidak semua bagian eksplan yang berkalus yang membentuk embrio somatik (Gambar 1e). Menurut Oktavia et. al., (2003), setiap jaringan memiliki respon yang berbeda dalam penyerapan zat pengatur tumbuh karena kebutuhan akan zat pengatur tumbuh pada eksplan masing-masing berbeda, oleh karena itu terkadang hanya dibutuhkan auksin, sitokini, tersendiri maupun secara bersamaan. Selain 2,4-D terdapat jenis zat pengatur tumbuh dari golongan sitokinin yang mampu menginduksi embriogenesis somatik salah satunya adalah Benziladenin, BAP, serta kinetin (Purmaningsih, 2004).

\section{Tekstur Kalus}

Tekstur kalus yang dihasilkan remah dan kompak (Tabel 2). Hal ini juga di sebabkan karena pengaruh berbagai konsentrasi zat pengatur tumbuh yang diberikan pada eksplan daun $V$. sumatrana. Hasil pengamatan menunjukan bahwa konsentrasi 2,4-D 2 dan 3 $\mathrm{mg} / \mathrm{L}$ mampu menbentuk embrio somatik dengan tekstur kalus yang remah dengan warna hijau kekuningan, Sedangkan pada konsentrasi $4 \mathrm{mg} / \mathrm{L}$ 2,4-D terbentuk kalus kompak namun tidak bersifat embrionik, karena konsentrasi 2,4-D memiliki batas optimum yang berbeda pada setiap tanaman. Menurut Indrianto (2003), struktur kalus yang remah bersifat embriogenik. selanjutnya menurut Yelnititis (2012) Warna kalus yang dianggap baik adalah warna kalus yang hijau, karena masih banyak mengandung klorofil.

Perbedaan tekstur kalus, kalus bertekstur kompak ditandai dengan tekstur yang padat dan sel-selnya sulit di pisahkan, sedangkan kalus bertekstur remah dengan selselnya mudah dipisahkan (Tabel 2). Sugiyarto, et, al. (2014) menyatakan bahwa kalus kompak mempunyai tekstur padat dan keras, yang tersusun dari sel-sel kecil yang sangat rapat, sedangkan kalus remah mempunyai tekstur lunak dan tersusun dari sel-sel dengan ruang antar sel yang banyak. Menurut Fintarti (2010) variasi tekstur yang terbentuk disebabkan oleh pengaruh pemberian auksin yang di tambahkan kedalam medium. Pierik (1987) menyatakan tekstur pada kalus dapat bervariasi dari kompak hingga meremah, tergantung pada jenis tanaman yang digunakan, komposisi nutrien media, zat pengatur tumbuh dan kondisi lingkungan kultur.

\section{Berat Basah Kalus}

Penambahan berbagai konsentrasi 2,4-D dapat meningkatkan berat basah kalus, mulai dari konsentrasi 2 hingga $4 \mathrm{mg} / \mathrm{L}$ 2,4-D (Tabel 3). Pada perlakuan kontrol, 1 dan 5 tidak memberikan respon terhadap berat basah kalus. George et al., (2008) menyatakan 2,4-D sering digunakan sebagai sumber auksin eksogen terutama untuk menginisiasi pembentukan kalus embriogenik pada proses embriogenesis somatik, tetapi embrio somatik tidak dapat terbentuk bila konsentrasi auksin terlalu tinggi. Perlakuan terbaik untuk peningkatan berat basah kalus terdapat pada konsentrasi $3 \mathrm{mg} / \mathrm{L}$ 2,4-D dimana berat basah kalus yang dihasilkan lebih tinggi dari perlakuan lainnya yaitu 1,776 g. Hal ini disebakan oleh aktifitas 2,4D yang mempengaruhi pertumbuhan eksplan. Menurut Rahayu et. al., (2003), berat basah kalus yang besar disebabkan karena kandungan airnya yang tinggi. Berat basah yang dihasilkan sangat tergantung pada kecepatan sel-sel tersebut membelah diri, 
memperbanyak diri dan dilanjutkan dengan membesarnya kalus. Penelitian ini sejalan dengan Indarjo (2003) yang mana pada penambahan 2,4-D dengan konsentrasi 2
mg/L 2,4-D menghasilkan berat basah kalus tertinggi pada anggrek Dendrobium jakarta molek .

Tabel 3. Rata-rata berat basah kalus eksplan daun V. sumatrana 12 minggu setelah tanam.

\begin{tabular}{cc}
\hline Perlakuan & Rata-rata berat basah $(\mathrm{g})$ \\
\hline A. Tanpa 2,4-D & $0,000 \mathrm{~d}$ \\
B. $1 \mathrm{mg} / \mathrm{L} 2,4-\mathrm{D}$ & $0,000 \mathrm{~d}$ \\
C. $2 \mathrm{mg} / \mathrm{L} 2,4-\mathrm{D}$ & $0,832 \mathrm{~b}$ \\
D. $3 \mathrm{mg} / \mathrm{L} 2,4-\mathrm{D}$ & $1,776 \mathrm{a}$ \\
E. $4 \mathrm{mg} / \mathrm{L} 2,4-\mathrm{D}$ & $0,248 \mathrm{c}$ \\
F. $5 \mathrm{mg} / \mathrm{L} 2,4-\mathrm{D}$ & $0,000 \mathrm{~d}$ \\
\hline
\end{tabular}

Keterangan :Angka-angka yang diikuti huruf yang sama pada kolom tidak berbeda nyata menurut uji $\mathrm{F}$ pada taraf $5 \%$ dan $1 \%$.

Adanya perbedaan berat kalus pada setiap perlakuan dikarenakan perbedaan laju pertumbuhan kalus yang dipengaruhi oleh zat pengatur tumbuh. Menurut Santoso dan Nursandi, (2004). Auksin mendorong elongasi sel terjadi pada arah vertikal dan diikuti dengan pembesaran sel dan peningkatan bobot basah. Arah perkembangan kultur ditentukan oleh interaksi dan perimbangan antara zat pengatur tumbuh yang diproduksi oleh sel tanaman secara endogen, akan tetapi dalam pertumbuhan dan perkembangan tanaman secara in vitro zat pengatur tumbuh eksogen masih dibutuhkan.

Pada perlakuan konsentrasi $4 \mathrm{mg} / \mathrm{L}$ dapat dilihat bahwa rata-rata berat basah kalus mengalami penurunan. Menurut Sriyanti (2000), pengukuran berat basah kalus masih sangat tergantung pada kandungan air dalam kalus, sehingga penurunan berat basah kalus kemungkinan besar disebabkan penurunan kandungan air dalam kalus. Perbedaan penurunan berat basah diduga oleh kemampuan jaringan dalam menyimpan air dan unsur hara yang berbeda. Penurunan berat basah kalus kemungkinan juga disebabkan karena kalus diduga telah memiliki hormon auksin endogen sehingga kandungan hormon pada media menjadi terlalu tinggi (Wattimena, 1991).

\section{Kesimpulan}

Dari penelitian yang telah dilakukan mengenai induksi embriogenesis somatik daun $V$. sumatrana dengan pemberian beberapa konsentrasi 2,4-D dapat disimpulkan bahwa embriogenesis somatik tahap globular yang dicirikan bertesktur remah mampu terbentuk pada pemberian 2,4D konsnetrasi 2 dan $3 \mathrm{mg} / \mathrm{L}$.

\section{Ucapan Terima Kasih}

Penulis mengucapkan terima kasih kepada Dr. Tesri Maideliza, Prof. Dr. Mansyurdin, dan Zuhri syam, MP yang telah memberikan saran, bimbingan dan ilmu pengetahuan hingga terselesaikannya artikel ini.

\section{Daftar Pustaka}

Arditti, J. and Ernst, R. 1993. Micropropagation of Orchid. John Wiley\& Sons Inc. New York.

Collin, H.A dan Edwad.S. 1998. Plant cell culture. BIOS Scientific Publisher. United Kingdom.

Comber, J. B. 2001. Orchids of Sumatra. The Royal Botanic Garden. Kew.

Deli, R.N, Noli, Z.A dan Suwirmen. 2015.respon Pertumbuhan Nodus Artemesia vulgaris L. Pada medium Murashige-Skoog dengan Penambahan Beberapa Zat Pengatur Tumbuh Secara 
In vitro. Jurnal Biologi Universitas Andala. 4(3) :162-168.

Dwiyani,. R. 2013. Induksi Kalus pada Tanaman Anggrek Vanda tricolor Lindl. Var. Suavis Upaya Penyediaan Target Transformasi Melalui Argobacterium tumefaciens. Jurnal Agrotropika. 18(2) : 73-76.

Edy, A dan Pujisiswanto, H. 2008. Pengaruh 2,4-D terhadap Induksi Embrio Somatik Eksplant Laevet pada Beberapa Varietas Kacang Tanah (Arachis hipogea) Secara in vitro. Prosiding Seminar Nasional Sains dan Teknologi II Universitas Lampung. : 17-18

Fadhilah, N. 2016. Induksi Embriogenesis somatik Artemesia vulgaris L. Dengan pemberian 2,4-D.\{Skripsi\}. Universitas Andalas. Padang.

Fintarti, M. 2010. Embriogenesis Somatik dari Kalus Peganggan (Centella asiantica L Urban) Dengan Pemberian 2,4-D. \{Skripsi\}. Universitas Andalas. Padang.

Gardner, F, P. Pearce,R. B, dan R. I, Mitchell. 1991. The Plantation of Vegetation Physicology. Academic press. London

George E.F., Hall M.A., Jan De Clerk G. 2008. Plant Propagation by Tissue Culture 3rd edition. Volume 1. The background. Springer. P: 183-197.

Hendaryono, D.P.S., dan A.Wijayani. 1994. Teknik Kultur Jaringan. Penerbit Kanisius. Yogyakarta. 139p.

Hoesen, D.S.H., Widjaksono., dan Sukamto LA. 2008. Induksi kalus dan Organogenesis Kultur/ZV-Vitro Dendrobium lineale Rofle. Berita Biologi 9(3) : 333-341.

Indah., P. N dan Ermavitalini, D. 2013. Induksi Kalus Daun Nyamplung (Calophyllum inophylum Linn.) pada Beberapa Kombinasi Konsentrasi 6Benzylaminopurine (BAP) dan 2,4-
Dichlorophenoxyacetic acid (2,4-D). Juranal Sains dan Seni POMITS. 2 (1): 2337-3520

Indarjo, S. 2003. Pengaruh pemberian zat ppengatur tumbuh NAA dan 2,4-D terhadap pembentukan kalus pada kultur invitro polen anggrek Dendrobium jakarta molek. $\{$ Skripsi $\}$. Fakultas kehutanan. IPB. Bogor.

Indrianto, A. 2003. Kultur Jaringan Tumbuhan. Fakultas Biologi Universitas Gadjahmada, Yogyakarta.

Klaus dan Haensch.T. 2007. Influence of 2,4$\mathrm{D}$ and BAP on callus growth and the subsequent regeneration of somatic embryos in long-term cultures of Pelargonium X Domesticum Cv. Madame Layal. Electronic Journal of Biotechnology 10(1): 69 - 77.

Latif, S.M. 1960. Bunga anggerik permata belantara indonesia. Sumur bandung. Bandung

Lestari, E.G. 2011. Peranan Zat Pengatur Tumbuh dalam PerbanyakanTanaman melalui Kultur Jaringan. Jurnal AgroBiogen 7(1):63-68

Lizawati, Neliyati, R., Desrfira. 2012. Induksi Kalus Eksplan Daun Durian (Durio Zibethinus Murr cv Selat Jambi) pada beberapa kombinasi 2,4-D dan BAP. 2012. Jurnal Online UNJA. 1 (1) : 2302-6472

Mariska, I., D. Sopandie, S. Hutami, E. Syamsudin, dan M. Kosmiatin. 2001. Peningkatan ketahanan terhadap Al pada tanaman kedelai melalui kultur in vitro. Laporan Riset Unggulan Terpadu VIII. Kantor Menristek dan LIPI, Jakarta.

Naing, A.H., J.D Chung dan K.B. Lim. 2011. Plant Regeneration throuhgt Indirect Somatic Embryogenesis in Coelogyne cristata Orchids. American Journal Of Plant Science. 2: 262-267. 
Narayanaswamy. 1994. Plant Cell and tissue Culture . Tata Mc Graw-Hill Publishing Company Limited. New Delhi.

Oktavia,. Fetrina,. Siswanto,. Budiani dan sudarsono. 2003. Embriogenesis somatik langsung dan regenerasi planlet kopi Arabika (coffea arabika) dari Berbagai Eksplan. Menara perkebunan 2003. 71 (02) : 45-55.

Pierik, R.L.M. 1987. In Vitro Of Higher Plants.Martunis Nijhoff. Publ.Dordrecht.344

Purmaningsih, R. 2004. Regenerasi tanaman melalui embriogenesis somatik dan beberapa gen yang mengendalikannya. Buletin Agrobio Balai penelitian Bioteknologi Tanaman Pangan. Bogor. 5(2):51-58.

Rahayu, B., Solichatun, dan E. Anggarwulan. 2003. Pengaruh Asam 2,4Diklorofenoksiasetat (2,4-D) terhadap Pembentukan dan Pertumbuhan Kalus serta Kandungan Flavonoid Kultur Kalus Acalypha indica L. Biofarmasi .1(1) :16.

Rianawati, S. Purwito, A. Marwoto, B. Kurniati, R dan Suryanah. 2009. Embriogenesis somatik dari eksplan daun Phalaenopsis sp L. J. Argon. Indonesia. 37(3):240-248.

Santoso, U. Dan Nursandi. F. 2004. Kultur jaringan tanaman. UMM Pers. Malang.

Sriyanti, D.P. 2000. Pelestarian Tanaman Nilam (Pogostemon heyneasus Benth.) melalui Kultur Mikrostek. Biosmart 2(2): 19-22.

Suwirmen. 2009. Induksi dan Multiplikasi Tunas Tumbuhan Andalas (Morus macroura Miq., var. macroura) secara In vitro dalam Konservasi Plasma Nutfah Mascot Flora Sumatra Barat. Berk. Penel. Hayati Edisi Khusus: 3D : 61-65

Utami, E.S.W., Sumardi, I., Taryono, dan . Semiarti, E. 2007. Pengaruh $\alpha-$
Naphtaleneacetic Acid (NAA) Terhadap Embriogenesis Somatik Anggrek Bulan Phalaenopsis Amabilis (L.) B1. Jurnal Biodiversitas. 8 (4) : 295-299.

Wattimena, G. A, L. W Gunawan, N. Mattjik, A, Syamsudin, E, Wiendi, N. M. A Ermwati. 1991. Bioteknologi Tanaman. PAU Bioteknologi. IPB Bogor.

Widuri LI, Dewanti, P. Soeparjono, S. 2015. Induksi somatik embriogenesis tanaman tebu transgenik SUT event 02 menggunakan 2,4-D dan BAP. Berkala Ilmiah Pertanian 1(1) : 1-5.

Yelnititis. 2012. Pembentukan Kalus Remah dari Eksplan Daun Ramin (Gonystylus bancanus (Miq) Kurz). Jurnal Pemuliaan Tanaman Hutan 6:181-194.

Zaid, A. 1987. Invitro Browning of Tissue and Media With Special Emphasis To Date Palm Culture. Acta Holticulture 21( 2): $561-566$ 